\title{
History and Bathymetry of a Surge-dammed Lake
}

\author{
SAM G. COLLINS ${ }^{1}$ and GARRY K.C. CLARKE ${ }^{2}$
}

\begin{abstract}
A survey was made in 1974 of the small lake which had formed as a result of the surge advance of Steele Glacier, Yukon Territory, in 1965-68. Maximum lake level is controlled by a drainage channel which passes over rock near the hydrologic left margin of Steele Glacier. Since the surge advance of 1965-68 the lake has twice drained subglacially, producing minor outburst floods on Steele Creek and increasing the discharge of the Donjek River which crosses the probable route of the Alaska Highway pipeline.
\end{abstract}

RÉSUMÉ. Histoire et bathymétrie d'un lac formé par une crue exceptionnelle d'un glacier formant barrage. On fit une étude, en 1974, du petit lac qui s'était formé à la suite d'une crue exceptionnelle, en 1965-68, du glacier Steele, dans le Territoire du Yukon. Le niveau maximum du lac est contrôlé par un canal de drainage qui passe par-dessus un terrain rocailleux non loin du bord hydrologique gauche du glacier Steele. Depuis la crue exceptionnelle de 1965-68, le lac s'est drainé par deux fois au-dessous de la couche de glace, occasionnant des crues subites peu importantes du Steele Creek et augmentant le débit du Donjek River qui traverse le parcours proposé pour la pipeline de la Route de l'Alaska.

РЕЗЮМЕ. История образования и батиметрия озера, образовавиегося при необыиным вздутии ледника. В 1974 году было проведено обследование озера, обравовавшегося в ревультате необычного вздутия ледника Стила /Юкон/ в 1965-68 гг. Максимальный уровень воды в озере регулируется дренажным каналом, проходящим над основной породой недалеко от левой гидрологической границы ледника Стила. После необычного вздутия ледника в период 1965-68 гг. озеро дважды осушалось подледниковым дренажем, приводя к небольшим паводкам на ручье Стила и увеличивая расход воды в р. Донджек. Нефтепровод, который предложено проложить вдоль аляскинской автомагистрали, должен пересекать эту реку.

\section{INTRODUCTION}

A surge of Steele Glacier in the St. Elias Mountains, Yukon Territory, occurred in 1965-68 and the displaced ice of the glacier's lower zone dammed the mouth of Hazard Creek, a tributary of Steele Creek. The lake which formed behind the dam (location: $61^{\circ} 15^{\prime} 24^{\prime \prime} \mathrm{N}, 140^{\circ} 12^{\prime} 30^{\prime \prime} \mathrm{W}$ ) filled some time between September 1966 and August 1967, and remained full until late July 1975, when it drained through a tunnel under the glacier. Throughout the summer of 1976, the basin remained empty, the waters of Hazard Creek discharging through the subglacial tunnel. The lake was again full in July 1977, but drained again shortly after.

Ice-dammed lakes are a common consequence of variations in glacier movement and are found in most glaciated regions. Surge-type glaciers, exceptionally abundant in the St. Elias Mountains, undergo exaggerated fluctuations of length and thickness, and are therefore especially active in producing ice dams. A recent

1927 Military Avenue, Council Bluffs, Iowa 51501, U.S.A.

'Department of Geophysics and Astronomy, University of British Columbia, Vancouver, B.C., Canada V6T 1W5 
report indicates there are probably more than 200 ice-dammed basins in the Slims, Donjek, and Generc-White river watersheds which drain the Canadian portion of the St. Elias interior slope north of $60^{\circ} 30^{\prime} \mathrm{N}$ latitude, and that there are some 280 surge-type glaciers in this same region (Canada 1977).

The main significance of ice-dammed lakes is their potential for unpredictable, catastrophic drainage, giving rise to brief, violent floods. According to Wood (1967), Steele Creek was considered a "forbidden valley" by local Indians who feared "annihilation from flood water and crashing ice" (Wood 1972). It is reasonable to assume that the fear was based on past experience with outburst floods. Thorarinsson (1939) discusses these phenomena in Iceland, where their effects are so striking that a special word for them (jökulhlaup) exists in the language. A general discussion of jökulhlaups with special reference to Canada, is provided by Young (1977), while Post and Mayo (1971) give a descriptive account of Alaskan examples. Recent theoretical analyses are given by Björnsson (1975) and Nye (1976). However, relatively few detailed measurements or largescale maps of ice-dammed lakes are to be found in the literature. Of the more than 200 ice-dammed basins which could discharge across the (Alaska Highway) route of the pipeline due to be constructed through the Yukon Territory, only the lake formed by the damming of Hazard Creek has been studied in any detail.

\section{SURVEYS AND BATHYMETRY}

A survey of the lake perimeter was carried out, and bathymetric measurements were made in July 1974 . The length of the lake was found to be $2.1 \mathrm{~km}$ and the maximum width $0.5 \mathrm{~km}$. Soundings, recorded at 90 random points, permitted construction of a bathymetric map (see Fig. 1). The greatest depth measured, in the easternmost sounding, was $38.7 \mathrm{~m}$. No soundings were attempted near the calving ice cliff, where the lake was assumed to be deepest. A topographic map of the Steele Glacier region was prepared at 1:50,000 scale, in 1967, by the

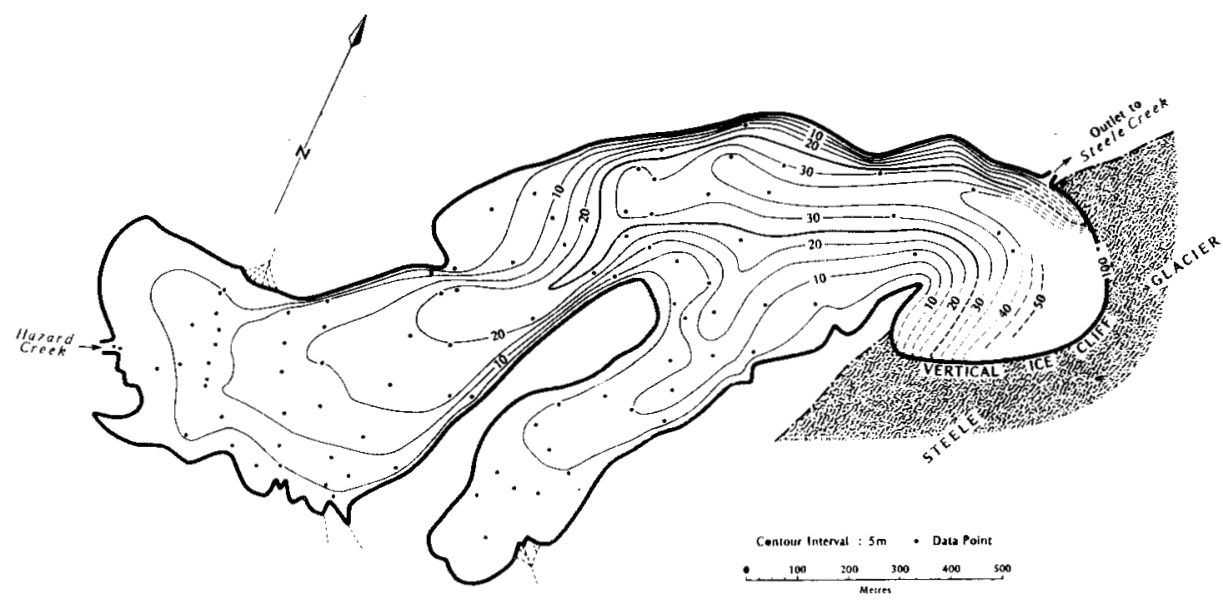

FIG. 1. Bathymetric map of lake formed by damming Hazard Creek. The UTM coordinates of the outlet to Steele Creek are F543372 N6792310, and the lake-surface altitude is $1,674 \mathrm{~m}$ above mean sea level. The contour interval is $5 \mathrm{~m}$. 
Canadian Topographical Survey from pre-surge photography (1951), but has not been published. The Hazard Creek portion of this map, photographically enlarged to the same scale as the lake map presented here, was found to correspond well with the bottom contours and lake outline when the two maps were superimposed, although the earlier map necessarily shows much less detail and no ice dam. The stream valley contours on the 1951 map indicated that the lake was approximately $100 \mathrm{~m}$ deep along the ice dam (Fig. 1). The volume of the lake, as computed by numerical integration, was 14 million $\mathrm{m}^{3}\left(14 \times 10^{6} \mathrm{~m}^{3}\right)$, while its mean depth was $16 \mathrm{~m}$ and its surface area $0.88 \mathrm{~km}^{2}$.

Vertical aerial photographs taken in the summer of 1951 (Fig. 2), the summer of 1955, August 1966 (Fig. 3), September 1966, August 1967, and the summer

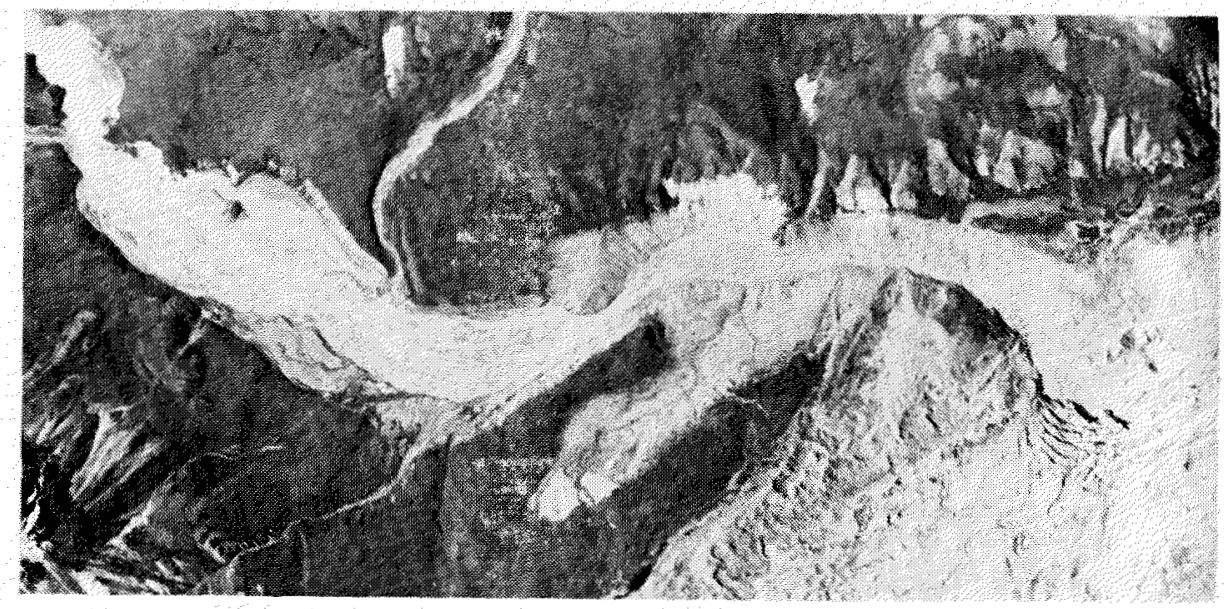

FG. 2. Portion of Canadian Government vertical aerial photograph A13132-164taken in the summer of 1951. The lake basin is empty and Hazard Creek drains along the hydrologic left margin of the stagnant tongue of Steele Glacier.

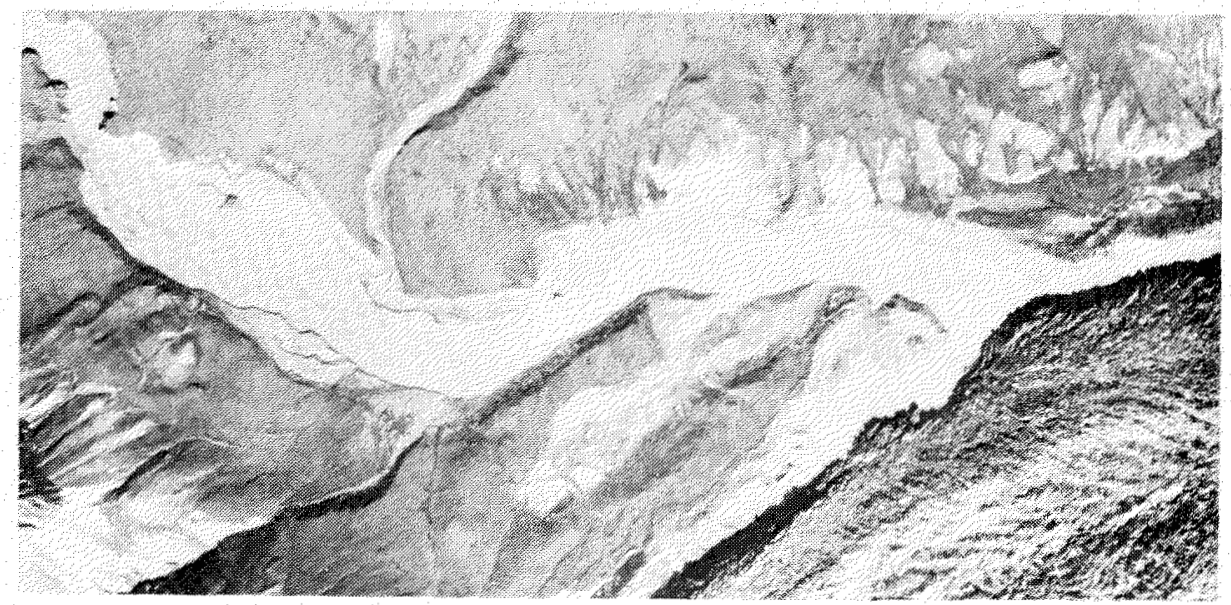

FIG. 3. Portion of Canadian Government aerial photograph A19647-42 taken in August 1966. The Steele Glacier advance has blocked the normal drainage of Hazard Creek and the lake basin is in the process of being filled. 


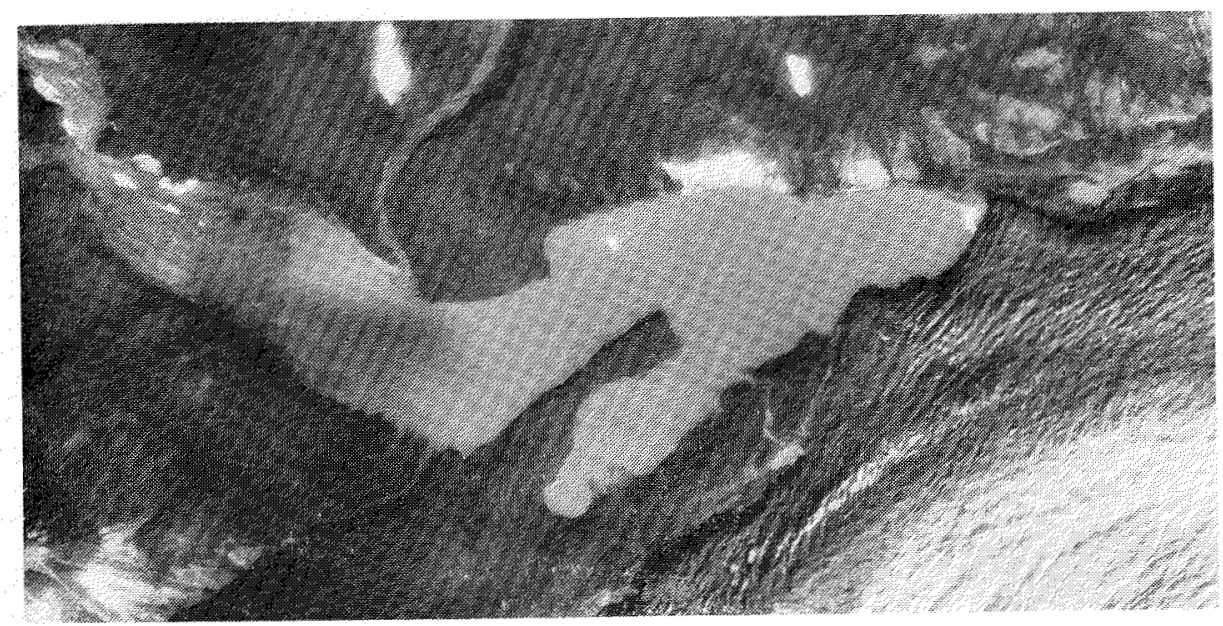

FIG. 4. Portion of Canadian Government aerial photograph A21523-77 taken in summer 1970. The lake basin is full and a stable drainage channel over rock has been found.

of 1970 (Fig. 4), together with aerial oblique photographs taken in January, February and May 1967 (M. Alford, Water Survey of Canada, Whitehorse, Y.T., personal communication) provide a comprehensive picture of the lake basin prior to the surge of 1965-68 and during the process of filling.

From earlier oblique photographs and ground surveys (Wood 1936; Sharp $1943,1951)$ it is evident that the basin remained empty over a period of at least thirty years preceding the surge of $1965-68$, and did not fill during the minor surge which occurred around 1947.

A delta, 300-350 m wide, the result of sedimentation from Hazard Creek, was found to fill the entire western end of the lake. Being of such size, it must have begun to form before 1967, although no attempt was made to estimate either the volume of sediments contained in it or the rate of their accumulation. Deltas present at the debouchments of small creeks into the basin also appeared to be larger than could be accounted for by only a decade of accumulation. Adjacent to the present delta, and a few metres higher than the most recent lake levels, were found extensive gravel terraces, well vegetated and containing willows 3-5 $\mathrm{m}$ in height. The stream appeared to have cut many channels into the terraces during the extended periods when they were not covered by water. During the last filling of the recent past - that which occurred before 1935 - the waters of the lake reached the approximate level attained after the surge of 1965-68. It was during an earlier filling that the old terraces were formed.

\section{PROCESSES OF FORMATION AND DRAINAGE}

The active phase of the Steele Glacier surge is thought to have begun late in 1965 (Stanley 1969). Aerial photographs taken in September 1966 (Fig. 3) show the normal course of Hazard Creek blocked by the Steele Glacier but the lake only partially filled. As the surge progressed, the ice level rose and a potential drainage channel along the hydrologic left margin of the glacier became blocked. Had the 


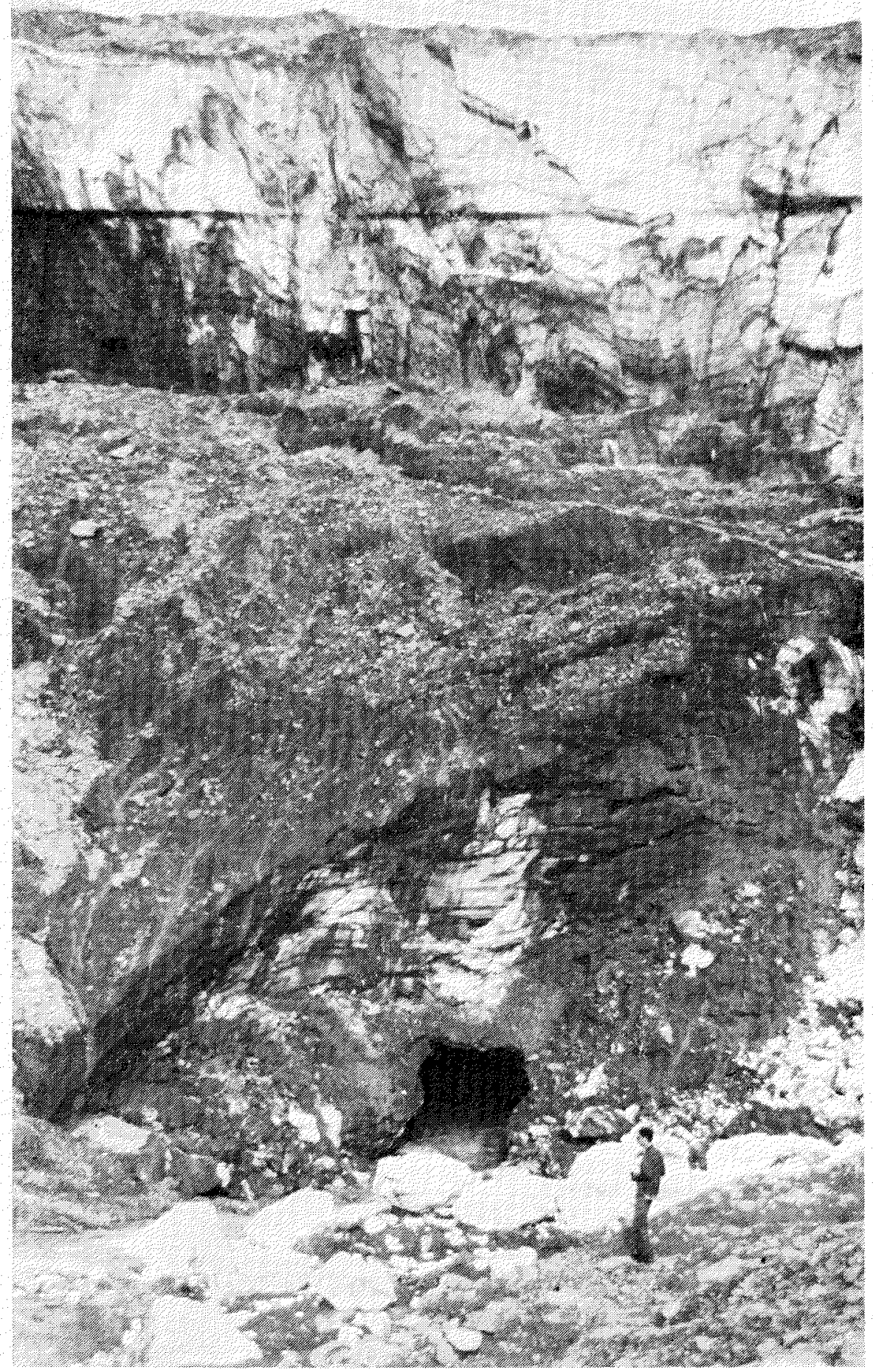

FIG. 5. Photograph taken 23 August 1976 showing empty lake basin and Hazard Creek entering subglacial drainage tunnel. The former lake level is seen as a horizontal lineation etched into the ice face. 
drainage stream maintained its course alongside the glacier, incision of the channel through the ice would have caused a gradual decline in water level. Instead, the lake continued to fill until drainage became possible through a rock-floored channel beyond the glacier margin and independent of the ice. This channel was established between May 1966 and August 1967 and the lake continued to be drained by it until, in late July 1975, the lake emptied through an ice tunnel under the glacier.

This event was fortuitously witnessed by R.B. Campbell of the Geological Survey of Canada (personal communication, 1977). While engaged in field work in the basin of Steele Creek, he noticed that the stream was in flood, although there had been no recent exceptional rainfall, and shortly thereafter he observed that the lake basin had emptied. In Fig. 5 are shown the ice face and drainage tunnel entrance at the basin's lowest point, as they appeared in August 1976. The former lake level appears as a clearly-cut horizontal line in the ice face near the top of the cliff. The presence of deep mud and lack of time prevented a closer approach to the opening and accurate measurement of it (estimated width 3-5 $\mathrm{m}$ ). It is conceivable that the lake had filled partially and drained again earlier in 1976; but in any case it refilled between September 1976 and July 1977. According to R.B. Campbell, who was again working in the Steele Creek basin at the time, the most recent emptying of the lake occurred after $31 \mathrm{July}$, and before 5 August, 1977. However, in photographs taken on 2 September 1977 (W. A. Wood, personal communication) the lake is seen to be full and draining through its "normal" rocky tunnel; the ice tunnel through which the lake drained a month previously must have closed almost immediately after that outburst event. If the pattern of behaviour of similar glacier-dammed lakes is followed, this cycle of filling and subglacial drainage will continue until ablation of the ice dam permits permanent drainage. There are two ways in which this may come about: either the height of the ice dam may so decrease that water is able to overtop the dam and cause the lake to drain supraglacially as a result of the incision of the drainage stream into the ice; or, alternatively, ice ablation may eventually reduce the glaciostatic pressure to such a degree that a subglacial drainage tunnel, once formed, will remain permanently open, instead of eventually becoming resealed by creep closure, as now happens.

Subglacial or englacial drainage becomes a possibility when the hydrostatic pressure in the neighbourhood of the ice dam becomes comparable to the glaciostatic pressure (Glen 1954). This condition can be brought about either by a raising of the lake level (increasing hydrostatic pressure) or by a lowering of the ice surface through ablation (reducing glaciostastic pressure). In the case of the lake formed as a result of the damming of Hazard Creek, the level cannot rise above the level of the rock-floored drainage channel near the glacier margin. Subglacial drainage does not occur until some years after formation of the ice dam, because surface melting must first bring about a lowering of glaciostastic pressure near the dam. Between surge episodes, the extended tongue of Steele Glacier is essentially motionless and ablates rapidly; flow rates measured in the area in 1974-75 were less than $2.0 \mathrm{~m}$ per year, and the average of four ablation measurements taken nearby was $2.65 \mathrm{~m}$ per year. In 1975 , the height of the ice dam above water level was measured at six points and found to average approximately $30 \mathrm{~m}$. 
Thus, in 1968, at the end of the surge of the Steele Glacier, the dam probably reached a height of more than $50 \mathrm{~m}$ above lake level.

From measurements of the drainage of Grimsvötn in Iceland (Björnsson 1975) and the most recent theoretical study of subglacial drainage (Nye 1976) it would appear that drainage can occur before the hydrostatic pressure actually exceeds glaciostatic pressure. The forces of buoyancy acting on bottom ice which is floating free of the bed exert leverage on the ice which remains attached to the bed. There is, as a result, a slight reduction in the threshold hydrostatic pressure required for subglacial drainage. It is worth noting that the Steele Glacier dam consists of cold (rather than temperate) ice, a condition thought to inhibit subglacial drainage. Temperature measurements taken deep in the ice in the vicinity of the ice dam (Clarke and Jarvis 1976) show that the temperature of the upper $100 \mathrm{~m}$ of glacier ice does not exceed $-1^{\circ} \mathrm{C}$.

Photographs taken in July 1977 of Steele Creek below the glacier terminus reveal no evidence of widespread flooding, although the boulder and gravel bars adjacent to the normal stream channel have a freshly-washed appearance, and several small alluvial fans, built onto the bars by minor tributaries, appear to have been truncated at bank-full level. The channel has a fairly steep gradient (approximately 0.018 ) and so, even though it is not broad and is only a few metres deep, it can contain the jökulhlaup of the draining lake without inundation of the wider vegetated floodplain. An estimate of the jökulhlaup magnitude is given by the empirical relationship developed by Clague and Mathews (1973): $Q=75 \mathrm{~V}^{0.67}$, where $Q$ is peak discharge (in $\mathrm{m}^{3}$ per second) and $\mathrm{V}$ is lake volume (in $10^{6} \mathrm{~m}^{3}$ ). This indicates that the maximum discharge to be reached in a jökulhlaup on Steele Creek would be around $440 \mathrm{~m}^{3}$ per second, or about two thirds of the maximum late-summer discharge carried by the Donjek River at the Alaska Highway bridge (Canada 1977) in the vicinity of the proposed pipeline crossing.

\section{ACKNOWLEDGEMENTS}

We thank M. Berkstresser, M. Smith and T. Tight for their assistance with the field programme and Dr. W.A. Wood for generously making available several hours of helicopter time. We also gratefully acknowldge the cooperation of Parks Canada (Kluane National Park). Our work was supported by grants from Environment Canada, the University of British Columbia Committee on Arctic and Alpine Research, the Arctic Institute of North America and the National Research Council (Canada).

\section{REFERENCES}

BJöRNsson, H. 1975. Explanation of jökulhlaups from Grimsvötn, Vatnajökull, Iceland. Jökull, 24:1-26.

CANADA. 1977. The influence of glaciers on the hydrology of streams affecting the proposed Alcan pipeline route. (Unpublished report on file at Glaciology Division, Inland Waters Directorate, Department of Fisheries and Environment, Ottawa.)

CLAGUE, J.J. and MATHEWS, W.H. 1973. The magnitude of jökulhlaups. Journal of Glacio$\log y$, 12(66):501-4.

CLARKE, G.K.C. and JARvis, G.T. 1976. Post-surge temperatures in Steele Glacier, Yukon Territory, Canada. Journal of Glaciology, 15(74):261-8.

GLEN, J.W. 1954. The stability of ice-dammed lakes and other water-filled holes in glaciers. Journal of Glaciology, 2(15):316-8. 
NYE, J.F. 1976. Water flow in glaciers: jökulhlaups, tunnels and veins. Journal of Glaciology, 17(76):181-207.

POST, A.S. and MAYO, L.R. 1971. Glacier dammed lakes and outburst floods in Alaska. U.S., Department of the Interior, Geological Survey, Hydrological Investigative Atlas HA-455.

SHARP, R.P. 1943. Geology of the Wolf Creek area, St. Elias Range. Bulletin of the Geological Society of America, 54:625-50.

Geology, 59(2):97-117.

STANLEY, A.D. 1969. Observations of the surge of Steele Glacier, Yukon Territory, Canada. Canadian Journal of Earth Sciences, 6(4):819-30.

THORARINSSON, s. 1939. The ice-dammed lakes of Iceland with particular reference to their values as indicators of glacier oscillations. Geografiska Annaler, 21(3-4):216-42.

WOoD, W.A. 1936. The Wood Yukon expedition of 1935: an experiment in photographic mapping. Geographical Review, 26(2):228-46.

1967. Glaciology: chaos in nature. Explorers Journal, 45(2):79-87.

1972. Steele Glacier, 1935-1968. In: Bushnell, V.C. and Ragle, R.H. (eds.), Icefield Ranges Research Project, Scientific results, Vol. 3. New York: American Geographical Society; Montreal: Arctic Institute of North America. pp. 1-8.

YoUNG, G.J. 1977. Glacier outburst floods. In: The influence of glaciers on the hydrology of streams affecting the proposed Alcan pipeline route. (Unpublished report on file at Glaciology Division, Inland Waters Directorate, Department of Fisheries and Environment, Ottawa.) 